\title{
Acrotylus insubricus (Orthoptera, Acrididae) rediscovered at the northern edge of its range after 60 years
}

\author{
Miloš Balla ${ }^{1}$, Anton Krištín ${ }^{2}$ \\ 1 Správa CHKO Latorica, J. Záborského 1760/1, 07501Trebišov, Slovakia \\ 2 Institute of Forest Ecology SAS, L. Štúra 2, 96053 Zvolen, Slovakia \\ Corresponding author: Anton Krištín (kristin@ife.sk)
}

Received 22 November 2019 | Accepted 19 December 2019 | Published 31 December 2019

Citation: Balla M, Krištín A (2019) Acrotylus insubricus (Orthoptera, Acrididae) rediscovered at the northern edge of its range after 60 years. Travaux du Muséum National d'Histoire Naturelle “Grigore Antipa” 62(2): 185-189. https://doi.org/10.3897/travaux.62.e48697

\begin{abstract}
The xerothermophilous grasshopper Acrotylus insubricus was found at a new, isolated site in Eastern Slovakia, at the northern boundary of its range. This is the first record in Slovakia after 60 years. In this paper this record is presented, with information on the habitat and accompanying species.
\end{abstract}

\section{Keywords}

Zoogeography, Orthoptera, sandy habitats, Slovakia

The Common Digging Grasshopper Acrotylus insubricus (Scopoli, 1786) is xerothermophilous species and the Afro-eremial faunal element (Rácz 1998). It is widely distributed in Africa and Eurasia, but in Europe it is found only in the southern part. The northern border of the range lies in Hungary (Nagy 2005), with some isolated sites in southern Slovakia (Čejchan 1961, Hochkirch et al. 2016, Fig. 1). It inhabits a variety of habitats, characterised by a fair amount of bare ground (Massa et al. 2012), e.g. mediterranean shrubland, grassland, dunes, but also a variety of anthropogenic habitats, such as gardens, pasture lands or urban areas. It prefers habitats with a fine soil, which enables it to dig into the ground, where it overwinters (Nagy 1958, Hochkirch 1998). In Slovakia, it is an endangered pseudopsammophilous species, which can be found together with other pseudopsammophilous species, 


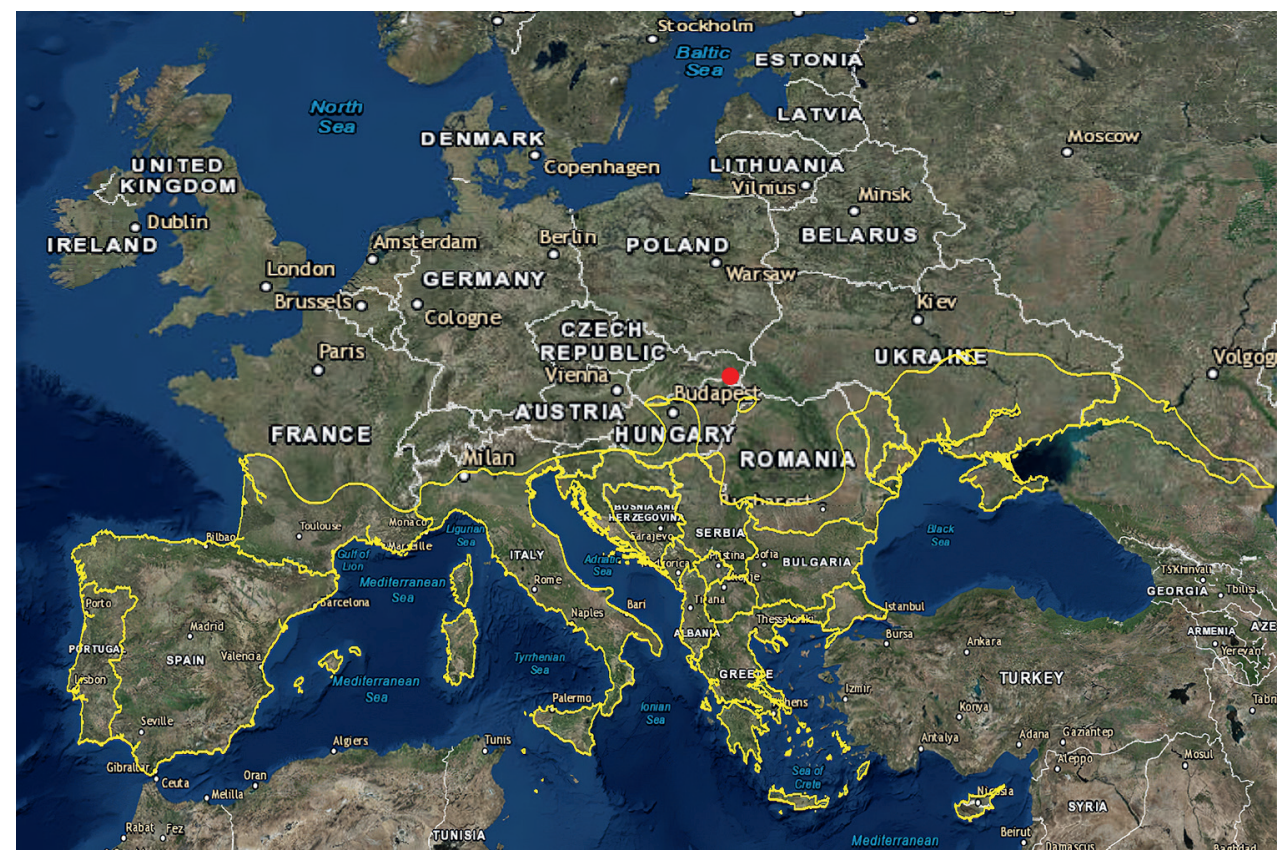

Figure 1. New site of Acrotylus insubricus in Slovakia (red dot) within its Europaean range (ex Hochkirch et al. 2016).

as Acrida ungarica, Myrmeleotettix antennatus, Acrotylus longipes and Oedaleus decorus (Mařan 1954, 1958, Gulička 1992, Krištín 2001). It was recorded from the Slovak area in the 19th century in Eastern Slovakia, near Somotor village (Chyzer 1897, Pungur 1900). It was documented as the northernmost site within its range. Additional findings include the same sandy site in E Slovakia (September 1951, one female, Mařan 1958), and three new sites in SW Slovakia: 1) Kováčovské kopce Mts near Štúrovo; April 1952, one female and August 24, 1955, several specimens (Mařan 1958), 2) sandy habitats in Chotín; August 25, 1960, $8{ }^{\wedge}$ and 79 (Čejchan 1961) and 3) sandy steppic grasslands near Čenkov; August 26, 1960, $60^{\lambda}$ and 79 (Čejchan 1961). The nearest documented occurrence to Slovakia were sporadic records in Hungary (Nagy 2005). Recently we discovered a population $(22+, 6 \hat{0}$ and 6 nymphs/1000 $\mathrm{m}^{2}$ ) in a sandy habitat site in N Hungary, near Szödliget village in August 28, 2019, about $23 \mathrm{~km} \mathrm{SE}$ of Slovak border (47.718N, 19.158E, $109 \mathrm{~m}$ a.s.l.).

In spite of the increased sampling effort in all the known and similar sites with sandy habitats of Slovakia in the last 25 years ( 1900 localities in 1994-2019, www. orthoptera.sk; Krištín et al. 2004a, 2004b, 2011), we were unable to confirm the presence of $A$. insubricus until 2019. In 2019, we found a small isolated population in northern part of Pannonian area of Eastern Slovakia, in a sandy site near Svätuše village (old name Plešany, GPS: $48.4197 \mathrm{~N}, 21.9386 \mathrm{E}$ ). We could establish a population of approximately $30-35$ individuals ( $2 / 3$ females, Fig. 2), during five visits (25. 
October -20 .November 2019). The autumn was relatively warm, with only three nights with ground frosts (daily $t_{\max }=13-19^{\circ} \mathrm{C}$ ). We expected to find A. insubricus also in two similar sites (Horeš and Strážne) with similar habitats, but no individuals were found there.

The population at Svätuše is distributed over approximately 1 ha $(120 \times 80$ m, $118 \mathrm{~m}$ a.s.l., Fig. 3). The site is characterized by bare sandy soils with scarce grassy and herbal vegetation of Festuca spp., Artemisia campestris (80\%), Polygonum aviculare, Eryngium campestre and other plants (20\%), in Festucion vaginatae association group. The habitat is similar to the one described in other regions (Nagy 1958, Hochkirch 1998, Rácz 1998). During the species mapping in the autumn, also other grasshopper species occurred there (Calliptamus italicus, Oedipoda caerulescens, Chorthippus mollis and Myrmeleotettix maculatus). Between 19972019, 43 Orthoptera species (18 Ensifera, 25 Caelifera) have been recorded from this area $\left(1 \mathrm{~km}^{2}\right)$, including other pseudopsammophilous and xerothermophilous species, e.g. Oedaleus decorus, Dociostaurus brevicollis, Myrmeleotettix antennatus, Euchorthippus pulvinatus, E. declivus, Gampsocleis glabra, Montana montana, Platycleis affinis and Tettigonia caudata. Despite of the intensive sampling efforts, the occurrence of congeneric species Acrotylus longipes could not be confirmed there. This species was found in the study area in 1960s by Gulička (1992), having a stable population approximately $110 \mathrm{~km}$ south from Slovak border in sandy habitats near Kecskemét (Nagy 1958).

The new site of $A$. insubricus is situated only $9 \mathrm{~km}$ east of the first described site in Slovakia (Somotor) around 1900 (Chyzer 1897, Pungur 1900). Therefore, we do not think that it is a recent spread of the species, but probably a long overlooked population.

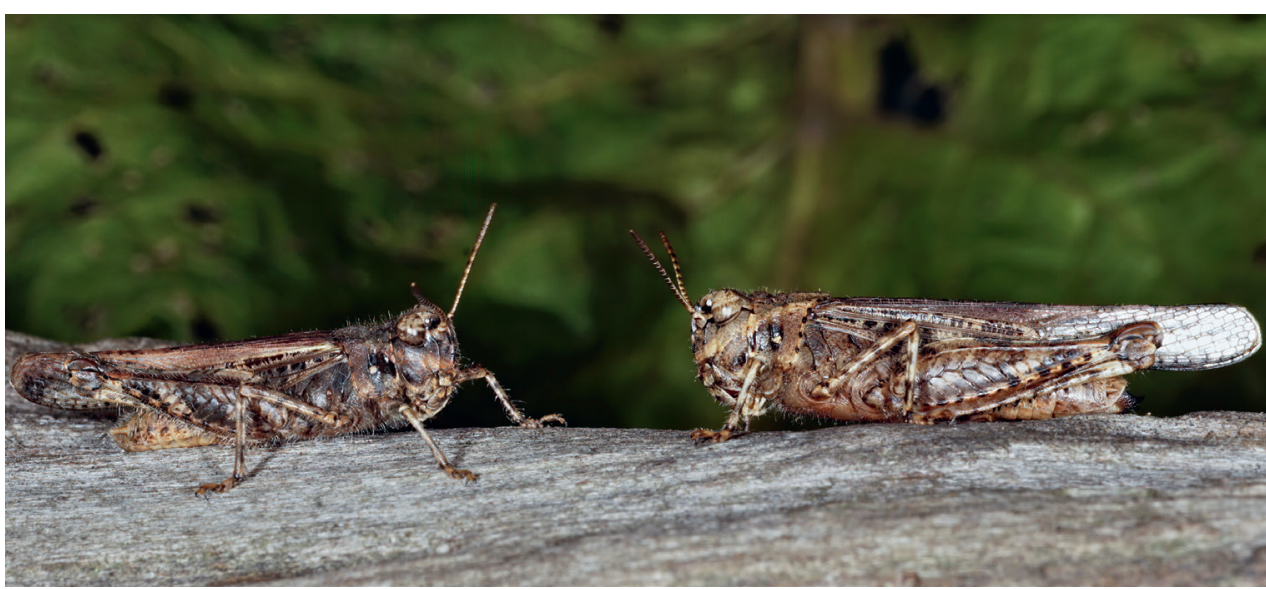

Figure 2. Acrotylus insubricus male and female (Svätuše, 14.11.2019, photo by M. Balla). 


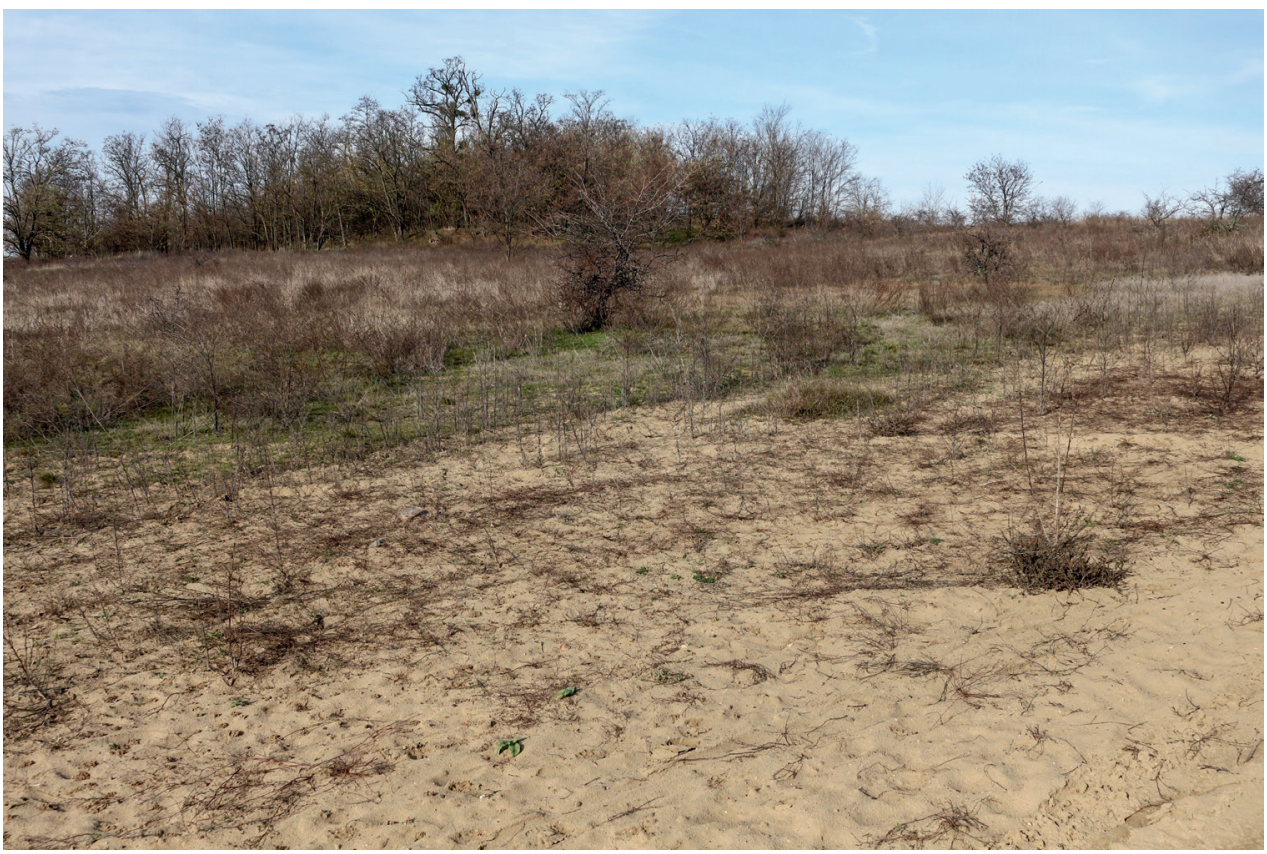

Figure 3. Sandy habitat of $A$. insubricus with ruderal vegetation in Eastern Slovakia (autumnal aspect, 20.11.2019, photo by M. Balla).

\section{References}

Čejchan A (1961) Poznámky k rozšíření druhu Acrotylus insubricus (Scopoli 1786) na Slovensku (Orthoptera, Acrididae) [Notes on Acrotylus insubricus (Scopoli 1786) distribution in Slovakia (Orthoptera, Acrididae)]. Časopis Slezského muzea, Vědy př́rodní 10: 68. [in Czech, English summary]

Chyzer K (1897) Zemplénvármegye Orthopterái [Orthoptera of the Zemplén district]. Rovartani Lapok 4: 99-101. [in Hungarian]

Hochkirch A (1998) Notizen zum Frühjahrsaspekt der Heuschreckenfauna bei Porto Covo (Baixo Alentejo, Portugal) [Notes on spring aspect of the Orthoptera fauna near Porto Covo (Baixo Alentejo, Portugal)]. Articulata 14(2): 127-144. [in German]

Hochkirch A, Szövényi G, Krištín A, Chobanov DP, Rutschmann F, Willemse LPM, Kleukers R, Presa JJ (2016) Acrotylus insubricus. The IUCN Red List of Threatened Species 2016: e.T15431156A70802618. Downloaded on 20 November 2019.

Gulička J (1992) Rovnokrídlovce [Crickets] (Caelifera, Ensifera). In: Škapec L. et al. (Ed.): Červená kniha ohrozených a vzácnych druhov rastlín a živočíchov ČSFR 3 Bezstavovce. Bratislava, Príroda, 70-73. [in Slovak]

Krištín A (2001). Červený (ekosozologický) zoznam rovnokrídlovcov (Orthoptera) Slovenska [Red (ecosozoological) list of grasshopper and crickets (Orthoptera) in Slovakia]. Ochrana prírody 20: 103-104. [in Slovak] 
Krištín A, Gavlas V, Balla M, Kaňuch P (2004a) Orthoptera and Mantodea of the EastSlovakian lowland (Východoslovenská nížina). Folia entomologica hungarica 65: 43-54. Krištín A, Kaňuch P, Sárossy M (2004b) Grasshoppers and crickets (Orthoptera) and mantids (Mantodea) of sand dunes in the Danube lowland (S Slovakia). Linzer biologische Beiträge 36: 273-286.

Krištín A, Balla M, Fabriciusová V, Hrúz V, Kaňuch P (2011) Orthoptera and Mantodea in fragments of seminatural habitats in lowlands of SE Slovakia and SW Transcarpathian Ukraine. Articulata 26: 109-121.

Mařan J (1954) Rovnokřídlý hmyz státních reservací v okolí Štúrova na jižním Slovensku. [The Orthoptera fauna of state nature reserves near Štúrovo in Southern Slovakia]. Ochrana prrírody 9: 132-139. [in Czech]

Mařan J (1958) Beitrag zur Kenntnis der geographischen Variabilität von Acrotylus insubricus (Scop.) (Orthoptera - Acrididae) [Note on the knowledge of the geographic variability of Acrotylus insubricus (Scop.) (Orthoptera - Acrididae)]. Acta Entomologica Musei Nationalis Pragae 32: 171-179. [in German]

Massa B, Fontana P, Buzzetti FM, Kleukers R, Odé B (2012) Fauna d'Italia - XLVIII Orthoptera. Calderini, Bologna. [in Italian]

Nagy B (1958) Ökologische und faunistische Angaben zur Kenntniss der Heuschrecken des Karpathenbeckens [Ecological and faunistic data on orthopterans of the Carpathians]. Folia entomologica hungarica 11, 9: 217-232. [in Hungarian]

Nagy B (2005) Orthoptera fauna of the Carpathian Basin - recent status of knowledge and revised check-list. Entomofauna Carpathica 17: 14-22.

Pungur J (1900) Ordo Orthoptera. In: Fauna Regni Hungariae III. Arthropoda. Societas scientiarum naturalium hungarica (A K. M. Natural Science Association), Budapest, pp. 3-16. [in Hungarian and Latin]

Rácz IA (1998) Biogeographical survey of the Orthoptera fauna in Central part of the Carpathian Basin (Hungary): Fauna types and community types. Articulata 13: 53-69. 